\title{
Scanning electron microscopy of the interaction between Cryptococcus magnus and Colletotrichum gloeosporioides on papaya fruit
}

\author{
Guy de Capdeville(1), Manoel Teixeira Souza Júnior(1), Jansen Rodrigo Pereira Santos(1), Simoni Paula Miranda ${ }^{(1)}$, \\ Alexandre Rodrigues Caetano(1), Rosana Falcão(1) and Ana Cristina Menezes Mendes Gomes ${ }^{(1)}$ \\ (1)Embrapa Recursos Genéticos e Biotecnologia, Av. W/5 Norte s/no, Final, Caixa Postal 02372, CEP 70770-900 Brasília, Brazil.
E-mail: guy@@cenargen.embrapa.br, msouza@cenargen.embrapa.br, jansen@cenargen.embrapa.br, simoni@cenargen.embrapa.br,
acaetano@cenargen.embrapa.br, falcao@cenargen.embrapa.br, anagomes@cenargen.embrapa.br
}

Abstract - The objective of this work was to investigate possible modes of action of the yeast Cryptococcus magnus in controlling anthracnose (Colletotrichum gloeosporioides) on post harvested papaya fruits. Scanning electron microscopy was used to analyze the effect of the yeast on inoculations done after harvest. Results showed that C. magnus is able to colonize wound surfaces much faster than the pathogen, outcompeting the later for space and probably for nutrients. In addition, $C$. magnus produces a flocculent matrix, which affects hyphae integrity. The competition for space and the production of substances that affect hyphae integrity are among the most important modes of action of this yeast.

Index terms: Carica papaya, anthracnose, antagonist yeast, biological control, competition.

\section{Microscopia eletrônica de varredura da interação entre Cryptococcus magnus e Colletotrichum gloeosporioides em frutos de mamão}

\begin{abstract}
Resumo - O objetivo deste trabalho foi investigar prováveis modos de ação da levedura Cryptococcus magnus, que resultam no controle da antracnose (Colletotrichum gloeosporioides) em frutos de mamoeiro na póscolheita. A microscopia eletrônica de varredura foi utilizada para avaliar o efeito da levedura sobre inoculações realizadas após a colheita. Os resultados mostraram que $C$. magnus é capaz de colonizar a superfície de ferimentos nos frutos e vencer a competição por espaço e, provavelmente, por nutrientes. Além disso, C. magnus produz uma matriz de textura característica que afeta a integridade da hifa do patógeno. A competição por espaço e a produção de substâncias que afetam a integridade das hifas estão entre os mais importantes modos de ação desta levedura.
\end{abstract}

Termos para indexação: Carica papaya, antracnose, levedura antagonista, controle biológico, competição.

\section{Introduction}

Colletotrichum gloeosporioides (Penz.) Penz. \& Sacc., the causal agent of anthracnose, is the most important postharvest pathogen of papaya fruit (Carica papaya L.). Although the fungus initiates infection during flowering and stays latent until conditions of postharvest environment can favor colonization of fruit tissue, and subsequent development of symptoms, this disease is characterized as a postharvest infirmity (Snowdon, 1990).

Fungicide dips and drenches and hot water baths after harvest have been the control strategies mostly used against anthracnose in papaya (Sholberg \& Conway,
2001). Nevertheless, if not conducted properly, postharvest control strategies such as hot bath or fungicide dipping may easily redistribute inoculum from field-infected fruit to noninfected and wounded ones (Wilson \& Wisniewski, 1995).

Increasing concerns with fungicide toxicity, development of fungicide resistance by pathogens, and potential harmful effects of fungicides have directed research efforts to select and test alternative control methods (Wilson \& Wisniewski, 1995; Capdeville et al., 2002), one of which is the use of antagonistic microorganisms (Wilson \& Wisniewski, 1995) during postharvest processing. This method has shown very promising results, ensuing on high rates of successful control of anthracnose on postharvested papaya fruit (Gamagae et al., 2004). 
Many antagonistic microorganisms have been tested as means to control diseases caused by different postharvest pathogens (Chalutz \& Wilson, 1990; Janisiewicz \& Bors, 1995; Chand-Goyal \& Spotts, 1996; Capdeville et al., 2002), but few studies have been published on the control of papaya postharvest diseases with this methodology (Gamagae et al., 2003, 2004). In general, control of plant diseases by yeast antagonists takes place with complex and diverse mechanisms. The control processes are dynamic and may involve the micro-ecology of the pathogen and antagonist, direct interaction between the pathogen and control agent, antibiosis, competition for space and nutrients, resistance responses of the host, and combinations between them (Wilson \& Wisniewski, 1995).

Capdeville et al. (2007) showed that, in papaya fruit, the yeast Cryptoccocus magnus can effectively control C. gloeosporioides inoculated after harvest, and therefore suppress the development of anthracnose.

The objective of the present work was to elucidate possible modes of action of $C$. magnus in inhibiting the development of $C$. gloeosporioides in papaya fruit tissue artificially inoculated after harvest.

\section{Material and Methods}

The research work was conducted at the Electron Microscopy Laboratory of Embrapa Recursos Genéticos e Biotecnologia, between 2005 and 2006. Papaya fruit used in the experiments were harvested at the commercial stage of ripening (two thirds of fruit surface showing yellow color) and were provided by two papaya growers from Southern Bahia State, in Northeastern Brazil.

An isolate (Cg-32) of Colletotrichum gloeosporioides, kept in the Plant Pathology laboratory of Universidade de Brasília, was used as source of inoculum for the experiments. The pathogenicity of the isolate was checked by inoculation of papaya fruit. Pieces of tissue were removed from the edges of lesions formed in those inoculated fruit, immersed in $70 \%$ ethanol for $1 \mathrm{~min}$, transferred to a solution of $1 \%$ sodium hypochlorite for $1 \mathrm{~min}$, washed three times for 2 min each in sterile distilled water, blotted on sterile filter paper, and plated on potato dextrose agar (PDA) medium supplemented with $0.1 \%$ streptomycin. The plates were incubated in a growth chamber at $24^{\circ} \mathrm{C}$, and after colonies were formed, disks of mycelium were removed from the edges of a colony and transferred to assay tubes containing PDA plus $0.1 \%$ streptomycin, allowed to grow for 5 days at $25^{\circ} \mathrm{C}$, and then stored at $5^{\circ} \mathrm{C}$. These stock cultures were tested for pathogenicity every two months. The stocks were used for generating new cultures grown on peptone glucose agar medium (PGA) for 7 to 10 days at $25^{\circ} \mathrm{C}$, from which spores were collected in sterile water. The final spore concentration in the suspension used as inoculum was adjusted to $10^{4}$ spores $\mathrm{mL}^{-1}$ with a hemacytometer.

A C. magnus strain capable of controlling C. gloeosporioides growth on papaya fruit, previously identified and characterized by Capdeville et al. (2007), was used in the present study. The yeast was cultivated on yeast extract agar medium (YMA) for 48 hours at $26^{\circ} \mathrm{C}$. A cell suspension at the concentration of $10^{8}$ cells $\mathrm{mL}^{-1}$ was then prepared with this material and was used to inoculate papaya fruit as described below.

Papaya fruit were harvested at the commercial harvest stage, washed with tap water, immersed in ethanol $70 \%$ for $1 \mathrm{~min}$ followed by immersion in $2 \%$ sodium hypochlorite for $3 \mathrm{~min}$, washed in sterile distilled water, and allowed to air dry. In each fruit, a $3 \times 3 \times 2 \mathrm{~mm}$ wound was made and received one of the following four treatments: fruit were wounded and not inoculated; fruit were wounded and inoculated with a $20 \mu \mathrm{L}$ drop of $C$. gloeosporioides spore suspension; fruit were wounded and inoculated with C. magnus by spraying the whole fruit surface, assuring that the wounds were fully covered with the cell suspension; and fruit were wounded and inoculated with both C. gloeosporioides and C. magnus. Application of the pathogen was performed at four different times $(0,24,48$, and 72 hours) after inoculation of the wound with the antagonist, and wound samples were dissected out at four different times $(0,24,48$, and 72 hours) after the treatments were applied.

After treatment, the fruit were placed in plastic trays and stored in a growth chamber at $25^{\circ} \mathrm{C}$ with $80 \%$ relative humidity. Each treatment was replicated three times (i.e. three different fruits). In total, 84 fruits were used in the study.

For the scanning electron microscopy studies, tissue sections of $3 \mathrm{~cm}$ in diameter around wounds (including the wound) were dissected out from each of the individual fruit used in the study. Dissected tissues were immersed in $2.5 \%$ glutaraldehyde in $0.1 \mathrm{M}$ sodium cacodylate buffer at $\mathrm{pH} 6.8$ for $30 \mathrm{~min}$, at room temperature, and cut into two halves. The samples were then transferred to a fresh solution of the same fixative for an additional $30 \mathrm{~min}$ at room temperature, and then for an additional $90 \mathrm{~min}$ at $4^{\circ} \mathrm{C}$. Samples were rinsed with the same buffer and postfixed for 2 hours, at room temperature, in $2 \% \mathrm{v} / \mathrm{v}$ osmium 
tetroxide in $0.1 \mathrm{M}$ sodium cacodylate, $\mathrm{pH}$ 6.8. The samples were dehydrated in a graded ethanol series and were dried using a BAL-TEC 030 CPD Critical Point Dryer. Dried samples were mounted on aluminum stubs and coated with gold-palladium using a BAL-TEC 050 sputter coater. The samples were examined using a Zeiss DSM 962 scanning electron microscope at $15 \mathrm{kV}$.
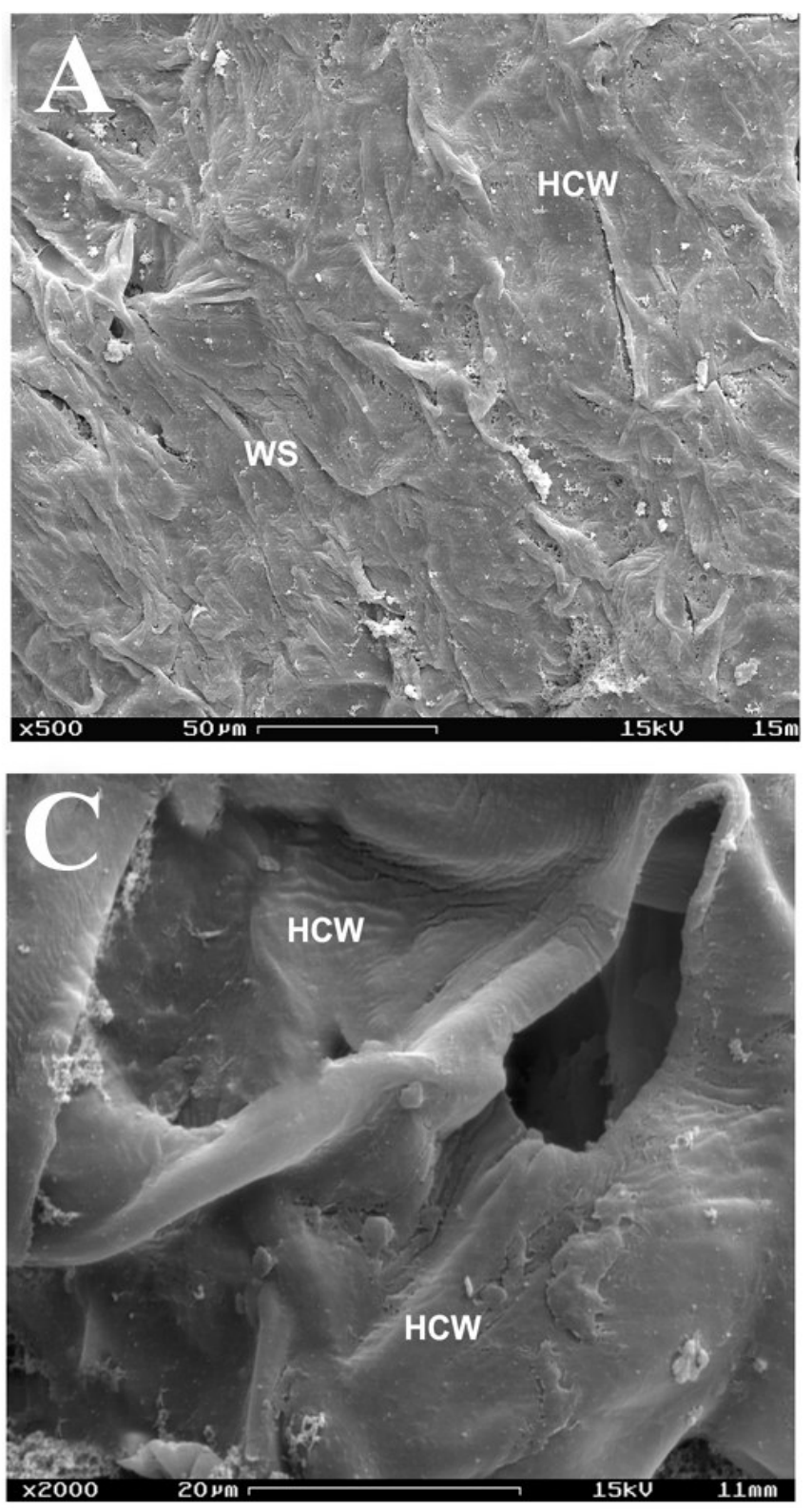

\section{Results and Discussion}

According to the results, in the treatment where the fruit were wounded but not inoculated, as expected, the wound surface was free of cells of both the antagonist and the pathogen (Figure 1). No healing alterations (Figure $1 \mathrm{~A}$ and $B$ ) were observed on the wound surfaces even in the times of 24 and 48 hours (Figure $1 \mathrm{C}$ and D).
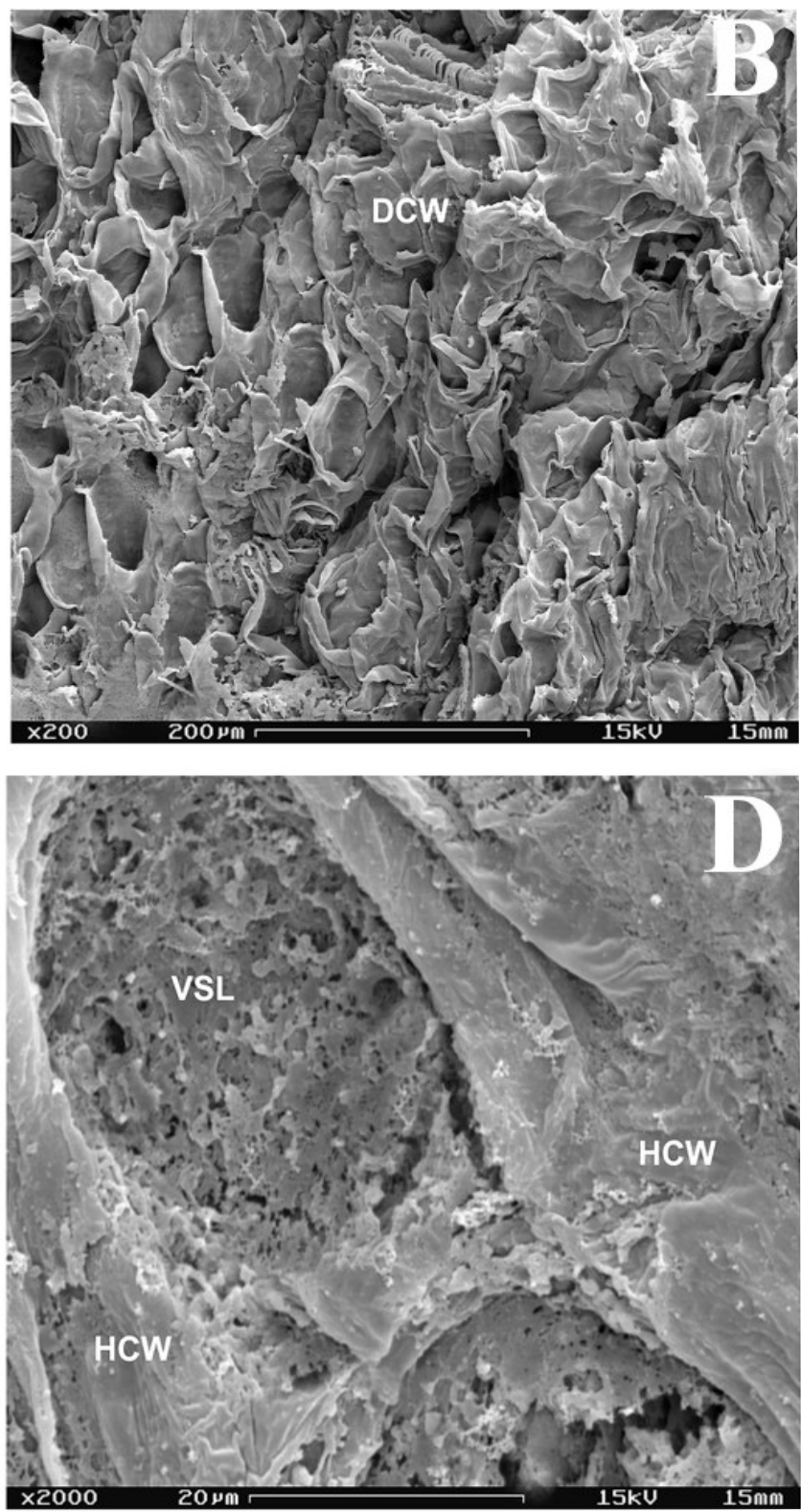

Figure 1. Scanning electron micrographs of papaya fruit wound surfaces not inoculated. A) Wound surface (WS) showing host cell wall (HCW) with a clean surface immediately after wounding. B) Wound surface showing damaged cell wall (DCW) due to wounding 24 hours after wounding. C) Detail of damaged host cell wall (HCW) with no healing alterations 48 hours after wounding. D) Image showing clean vascular system lumen (VSL) and host cell walls (HCW) in the wound surface 72 hours after wounding. 
Analysis of micrographs taken from wound surfaces inoculated with the pathogen alone showed that spores of the fungus did not initiate germination before 24 hours of inoculation (Figure $2 \mathrm{~A}$ and B). At 48 hours after inoculation, spores had germinated and appressoria were formed in many penetration points (Figures $2 \mathrm{C}$ and D). It was observed that, as soon as the spore germinated, appressoria were formed in a short distance from the spore. To the extent of our knowledge, no reference to this penetration behavior has been made in other publications.

In the treatments where wound surfaces were treated with $C$. magnus, dispersed yeasts cells could be seen colonizing the wound already at the earliest time after
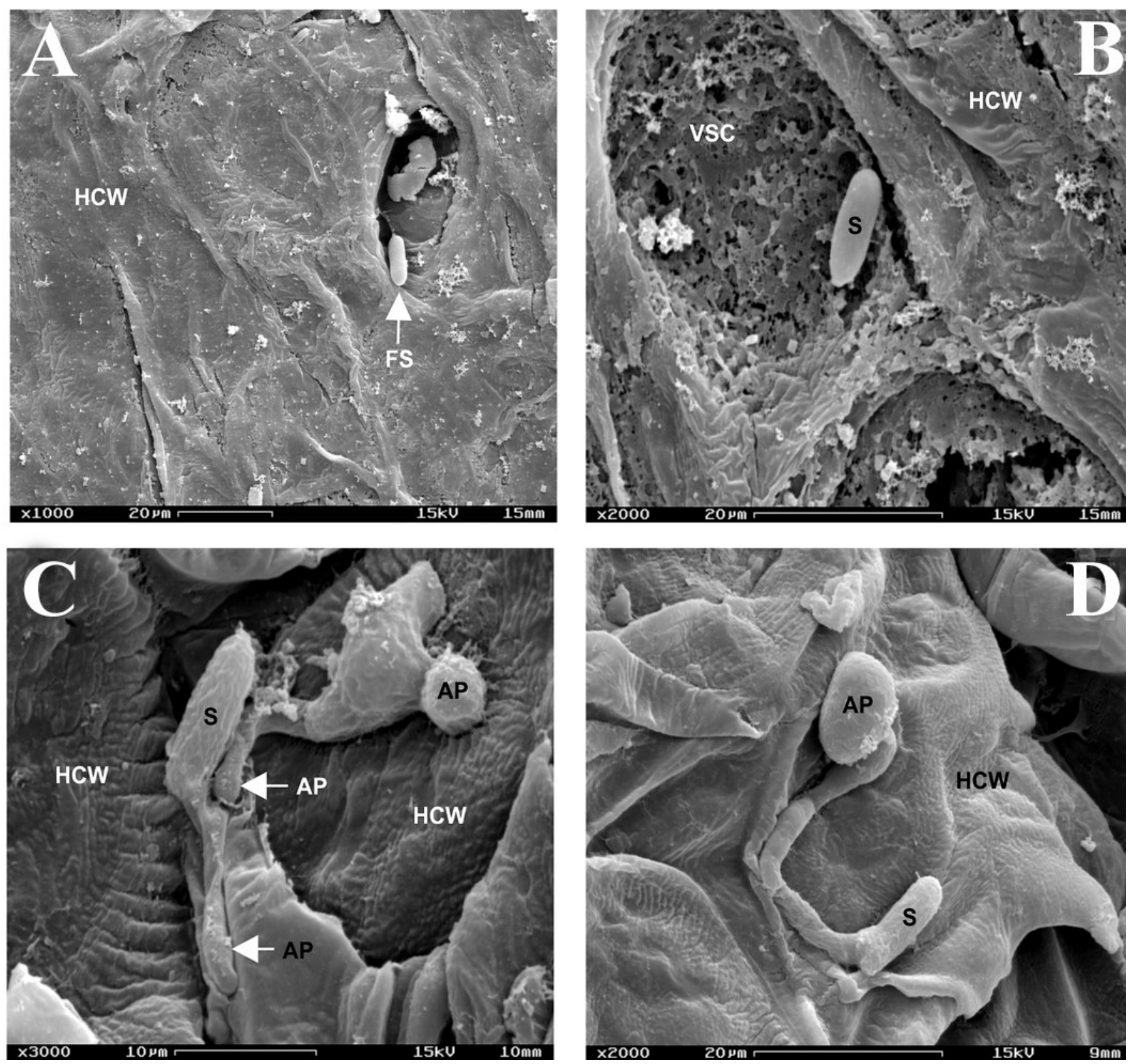

Figure 2. Scanning electron micrographs of surfaces of papaya fruit wounds inoculated with C. gloeosporioides. A) Wound surface showing host cell wall (HCW) and a single fungal spore (FS) on a damaged cell just after inoculation with the pathogen. B) Detail of a spore (S) over a vascular system cell (VSC) close to the host cell wall (HCW) 24 hours after inoculation. C) Detail of germinated spores (S) forming appressoria (AP) in different points of the host cell wall (HCW) 48 hours after inoculation. D) Detail of a germinated spore $(\mathrm{S})$ with the formation of an appressorium on the host cell wall 72 hours after inoculation. 
inoculation (Figure 3 A). After 24 hours of inoculation with the yeast, wound surfaces were almost completely covered with yeast cells (Figure 3 B). At later times (48 and 72 hours) after inoculation, not only yeast cells had colonized the entire wound surface, but also a flocculent matrix began to cover the yeasts and, in some cases, it covered the wound surface completely
(Figure $3 \mathrm{C}$ and D). The presence of the flocculent matrix was always associated with the presence of the yeast indicating that this matrix was indeed produced by the yeast cells.

In the treatments where both the antagonist and the pathogen were applied to the wound surface, at time zero, $C$. gloeosporioides spores could be easily seen
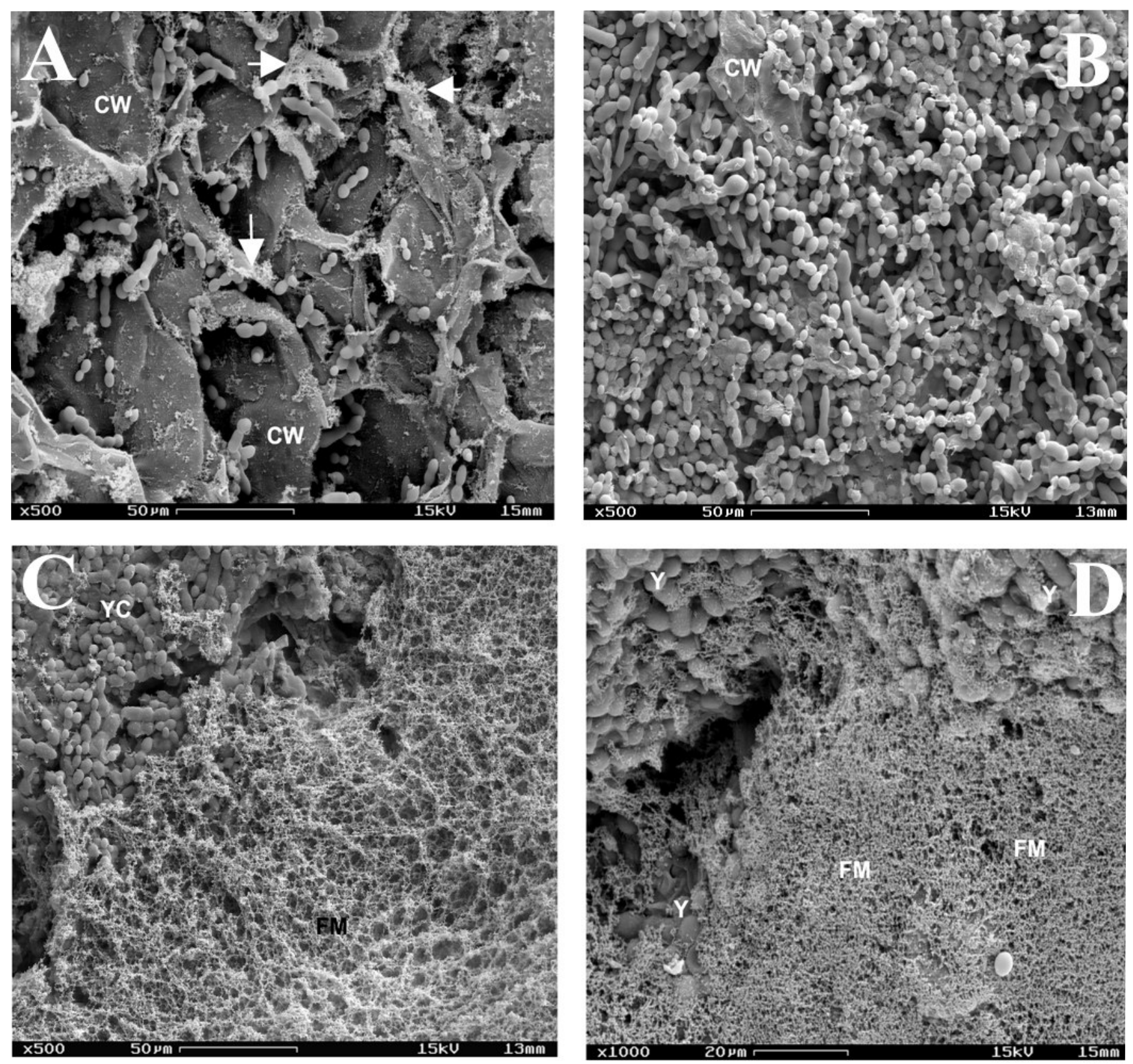

Figure 3. Scanning electron micrographs of papaya fruit wound surfaces inoculated with the antagonist. A) Wound surface showing many yeast cells on the cell wall (CW) of the host, immediately after inoculation with Cryptococcus magnus. B) Wound surface completely covered with $C$. magnus cells only 24 hours after inoculation. Note that only a small area of a host cell wall is not covered with the antagonist cells. C and D) Different areas of the wound surface completely covered with yeast cells (YC), and a flocculent matrix (FM) covering the yeasts (Y) 48 and 72 hours after inoculation, respectively. 
among yeast cells (Figure 4 A). However, 24 hours after inoculation with $C$. magnus, the wound surface was completely covered by yeast cells and the flocculent matrix, and no spores of the fungus were seen, regardless of the time of inoculation with C. gloeosporioides took place (Figure 4 B). In very few samples, it was possible to observe mycelia of the fungus growing over yeast cells, but in these situations it could be seen that the hyphae were always covered by the flocculent matrix an had a plasmolized aspect (Figure $4 \mathrm{C}$ ). In later sampling times, wound surfaces were completely covered by
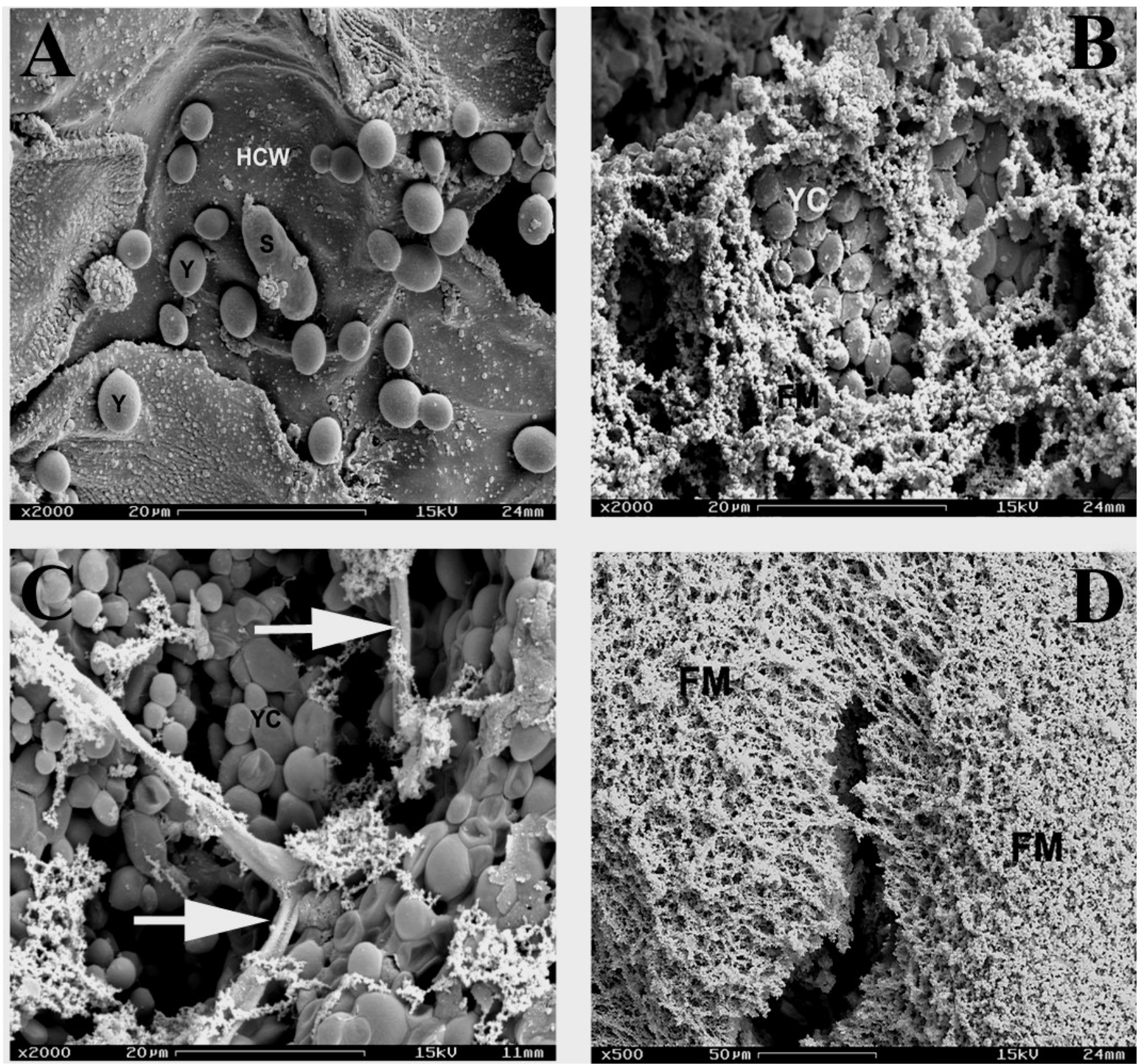

Figure 4. Scanning electron micrographs of papaya fruit wound surfaces inoculated with both the antagonist and the pathogen. A) Wound surface showing yeast (Y) cells around a spore (S) of Colletotrichum gloeosporioides deposited on a host cell wall (HCW) just after the inoculation. B) Yeast cells (YC) covered by the flocculent matrix (FM), 24 hours after inoculation with both the pathogen and the antagonist. C) Wound surface completely covered by yeast cells (YC). Hyphae of the pathogen appear plasmolized. D) Wound surface totally covered by the flocculent matrix (FM) 72 hours after inoculation. 
the flocculent matrix, and no cells either from the yeast or from the pathogen could be seen (Figure 4 D).

Capdeville et al. (2007) showed that an isolate of C. magnus effectively controlled C. gloeosporioides growth and infection in papaya fruit. C. magnus was able to colonize wound surfaces much faster than the pathogen, outcompeting the later for space and probably for nutrients. In addition, C. magnus produced a flocculent matrix which affected hyphae integrity.

One of the most probable modes of action of C. magnus in inhibiting the development of C. gloeosporioides in papaya fruit tissue is related to the large ability the yeast has to compete with the fungus for space and possibly for nutrients. C. magnus was able to colonize and cover the entire wound surface as early as 24 hours after inoculation. Considering that the pathogen initiates elongation of the germ tube only after 6 to 8 hours, it cannot effectively compete with the yeast for space and nutrients. In addition, the flocculent matrix found in wounds of fruit treated with C. magnus may have a major role in the interaction with the fungus. Whenever hyphae of $C$. gloeosporioides were covered or in contact with the flocculent matrix they became plasmolized, indicating that this material affected hyphae integrity. Different authors have suggested that production of extracellular matrices by yeasts may play a key role in disease control by either enhancing nutrient competition or by some other mechanisms yet to be determined (Wisniewski et al., 1991; Jijakli \& Lepoivre, 1998).

The production of extensive extracellular matrices by yeasts has been reported elsewhere (Jijakli \& Lepoivre, 1998; Wan \& Tian, 2002). Chan \& Tian (2005) have shown that the antagonistic yeast Pichia membranaefaciens is able to produce a matrix that encircles fungal hyphae affecting their integrity. However, the amount of matrix produced by $P$. membranaefaciens, mentioned in that paper, is much smaller than the amount produced by C. magnus, as it can be observed in Figures 3 and 4.

Chan \& Tian (2005) have shown that the most probable mode of action of the yeasts, in controlling postharvest pathogens of apple fruit, was adhesion of the yeast cells to the fungal hyphae cells and release of extracellular enzymes, such as beta-glucanase and chitinase, which affect cell wall integrity. Although C. magnus may produce such enzymes, adhesion to fungal cell wall is not a mode of action for this yeast, since yeast cells were only casually attached to fungal cells. Other Cryptoccocus species have been studied for their modes of action, and attachment to fungal hyphae and production of extracellular enzymes seem to have an effect on pathogens (Qin \& Tian, 2005). In order to unveil the chemical composition of the observed flocculent matrix, as well as to determine if $C$. magnus produces pathogenesis of related enzymes, more detailed work must be done. At the present level of knowledge about this pathosystem, it is certain that competition for space and production of substances that affect hyphae integrity are among the most important mechanisms of action used by $C$. magnus.

\section{Conclusions}

1. Cryptococcus magnus is more effective in competing for space on fruit surface than Colletotrichum gloeosporioides.

2. C. magnus produces a flocculent matrix that affects $C$. gloeosporioides hyphae integrity.

3 . The above modes of action of C. magnus contribute significantly for the success of this yeast as a biocontrol agent for anthracnose of papaya.

\section{Acknowledgements}

To Dr. Marisa Álvares da Silva V. Ferreira, from the Plant Pathology Department of Universidade de Brasília, for providing the isolate of Colletotrichum gloeosporioides used in the experiments; to Empresa Brasileira de Pesquisa Agropecuária (Embrapa), for the financial support.

\section{References}

ALVAREZ, A.M.; NISHIJIMA, W.T. Post harvest diseases of papaya. Plant Disease, v.71, p.681-686, 1987.

CAPDEVILLE, G. de; SOUZA, M.T.; SANTOS, J.R.P.; MIRANDA, S.P.; CAETANO, A.R.; TORRES, F.A.G. Selection and testing of epiphytic yeasts to control anthacnose in posts-harvest of papaya fruit. Scientia Horticulturae, v.111, p.179-185, 2007.

CAPDEVILLE, G. de; WILSON, C.L.; BEER, S.V.; AIST, J.R. Alternative disease control agents induce resistance to blue mold in harvested 'Red Delicious' apple fruit. Phytopathology, v.92, p.900-908, 2002.

CHALUTZ, E.; WILSON, C.L. Postharvest biocontrol of green and blue mold and sour rot of citrus fruit by Debaryomyces hansenii. Plant Disease, v.74, p.134-137, 1990.

CHAN, Z; TIAN, S. Interaction of antagonistic yeast against portharvest pathogens of apple fruit and possible mode of action. Postharvest Biology and Technology, v.36, p.215-223, 2005. 
CHAND-GOYAL, T.; SPOTTS, R.A. Postharvest biological control of blue mold of apple and brown rot of sweet cherry by natural saprofitic yeasts alone or in combination with low doses of fungicides. Biological Control, v.6, p.253-259, 1996.

GAMAGAE, S.U.; SIVAKUMAR, D.; WIJESUNDERA, R.L.C. Evaluation of posts-harvest application of sodium bicarbonateincorporated wax formulation and Candida oleophila for the control of anthracnose of papaya. Crop Protection, v.23, p.575-579, 2004.

GAMAGAE, S.U.; SIVAKUMAR, D.; WILSON, R.S.W.; WIJESUNDERA, R.L.C. Use of sodium bicarbonate and Candida oleophila to control anthracnose in papaya. Crop Protection, v.22, p.775-779, 2003.

JANISIEWICZ, W.J.; BORS, B. Development of a microbial community of bacterial and yeast antagonists to control woundinvading postharvest pathogens of fruits. Applied Environmental Microbiology, v.61, p.3261-3267, 1995.

JIJAKLI, M.H.; LEPOIVRE, P. Characterization of an exo- $\beta$ 1,3-glucanase produced by Pichia anomala strain K, antagonist of Botrytis cinerea on apples. Phytopathology, v.88, p.335-343, 1998.

QIN, G.Z.; TIAN, S.P. Enhancement of biocontrol activity of Cryptococcus laurentii by silicon and the possible mechanisms involved. Phytopathology, v.95, p.69-75, 2005.
ROBS, C.F. Enfermidades de pós-colheita do mamão. In: MENDES, L.G.; DANTAS, J.L.L.; MORALES, C.F.G. (Ed.). Mamão no Brasil. Cruz das Almas: EUFBA/Embrapa-CNPMF, 1996. p.89-91.

SHOLBERG, P.L.; CONWAY, W.S. Postharvest pathology. 2001. 38p. Avaliabe on: http://www.ba.ars.usda.gov/hb66/ 022pathology.pdf. Accessed on: June 19, 2001.

SNOWDON, A.L. Color atlas of post-harvest diseases and disorders of fruit and vegetables. Boca Raton: CRC Press, 1990. v.1.

WAN, Y.K.; TIAN, S.P. Antagonistical mode of Pichia membranefaciens to Rhizopus stolonifer in wounds of peach fruit by scanning electron microscope. Acta Botanica Sinica, v.44, p.1384-1386, 2002.

WILSON, C.L.; WISNIEWSKI, M.E. Biological control of postharvest diseases of fruits and vegetables: theory and practice. Boca Raton: CRC Press, 1995. 182p.

WISNIEWSKI, M.; BILES, C.; DROBY, S.; MCLAUGHLIN, R.; WILSON, C.; CHALUTZ, E. Mode of action of the postharvest biocontrol yeast, Pichia guilliermondii. I. Characterization of attachment to Botrytis cinerea. Physiological and Molecular Plant Pathology, v.39, p.245258, 1991.

Received on June 21, 2007 and accepted on October 26, 2007 